Мирослав Младеновић

УДК: 323.22

Универзитет у Београду

Ориіинални научни рад

Факултет безбедности

Примљен: 31. 7. 2012.

\title{
Јелена Пономарева
}

Московски државни институт

за међународне односе МСП Русије - МГИМО

\section{Зоран Килибарда}

Универзитет у Београду

Факултет безбедности

\section{ТЕОРИЈА И ПРАКСА "ШАРЕНИХ РЕВОЛУЦИЈА"1}

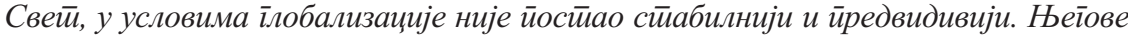

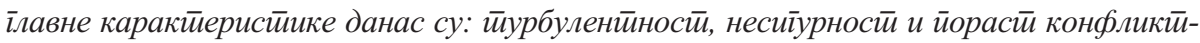

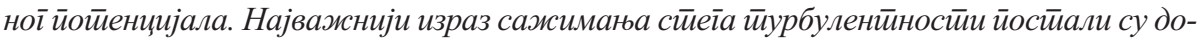
їађаји из 2011. іоодне, који су се дешавали у низу земаља Северне Абрике и Блискоі исйока, названи "арайске револуције". За неке, иии доїђаји су случајности и сииихијни иройесіи "санара о демокрайији", док су за друіе - йоследица йланске реализације кон-

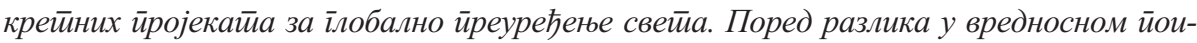

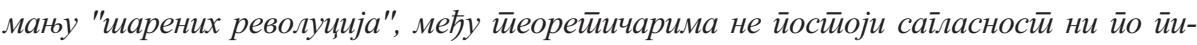

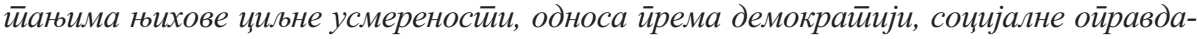
ностии и, нарочитио - сайласностии йостиављених цииьева и средстиава којима се они досийиху.

Кључне речи: "чарена револуција", ілобализација, демокрайија, "мека сила", "арайско ӥролеће".

Какву т̄и йоследюу револуцију хоћеш?

Последне нема, револуције су бесконачне.

Јевгениј Замјатин: $M u$

${ }^{1}$ Овај рад је резултат пројекта, број III 47029 под називом “Ренииабилни избор нових ииехнолойија и конщейиија одбране кроз друшиивене иромене и сиирайешке оријенйације Србије у 21. веку“. Пројекат финансира Министарство науке и технолошког развоја Републике Србије, а руководилац пројекта је проф. др Момчило Милиновић. 


\section{1. "Борба" за демократију}

Један од највидљивијих облика деловања на пољу промене актуелне геополитичке стварности јесу "шарене револуције", у зависности од ситуације, називане: "наранџаста" (Украјина), "револуција ружа" (Грузија), "револуција лала" (Киргизија), и сл. За ову појаву, западни теоретичари углавном користе термин "изборне револуције", чиме се потенцира чињеница промене власти од стране незадовољних грађана, изазвана неправилностима у оквиру изборног процеса (видети шире у: Bunce, Wolchik, 2005).

Мислиоци са Запада, "шарене или изборне револуције" најчешће посматрају као облик демократских пробоја у деловима света у којима владају различите форме аутократске власти. Истовремено, то је и процес ширења демократије западног типа. С друге стране, писци источне провенијенције, оваква настојања сматрају злоупотребом идеје демократије, државним ударима и тежњама Запада, пре свега САД, да на релативно миран начин прекрајају геополитичку карту света, нарочито у подручјима у којима имају изражен сопствени, економски, војни или политички интерес. Код ове дихотомије (Исток-Запад) треба имати у виду ограничености методе генерализације. С обзиром да се о "шареним" односно "изборним револуцијама" пише и говори, не само у теоријским и научним круговима, већ много више у оквиру политичких форума и публицистичких и интересних удружења, појмом "западна" и "источна" схватања проблема "шарених револлуција", углавном се означава идеолошко-политичко поимање ове поjаве. Због тога ће се и у овом раду, под одредницом "западни" односно "источни", превасходно подразумевати идеолошки и вредносни концепт, а не чисто научно-теоријски. Што се тиче научне анализе, она је објективна и у могућој мери вредносно неутрална па је, због тога, неумесно говорити о дијаметралној супротстављености западне и источне научне мисли, када се ради о тумачењу суштине "шарених револуција" или било ког другог дела објективне стварности. Разлике, које се и у оквиру научне сфере ипак појављују, највећим делом проистичу из различитих општефилозофских метода које се, као основа истраживања, примењују у једном и у другом делу света. Док је база целокупне западне мисли - прагматизам, упрошћено приказан по формули: "истина је једна врста добра, она се своди на успешност односно корисност неке идеје" (Калин, 1988: 171), то јест, истинито је оно што је корисно, на Истоку се истина тумачи према Аристотеловој теорији адеквације, према којој: истина је сагласност (дела) објективне стварности са мишљењем о тој стварности. Ова разлика видно се изражава и у процесу ангажованости науке у једном и другом концепцијски-филозофском систему. Наука на Истоку је изолованија и неусклађенија са основним токовима развоја друштва, док је на Западу она директно укључена у главне друштвене процесе. Западном систему вредности, својствен је и чест практични 
ангажман делатника науке при решавању важних питања друштва и државе (задатак теорије није само да "тумачи свет, већ да га мења"), док на Истоку, у најбољем случају, носиоци права одлучивања повремено само консултују научна достигнућа из области која се разматра.

Други теоријски проблем који се намеће у процесу сагледавања суштине "шарених револуција", јесте веома различито тумачење појма демокрайија, који се увек истура као разлог и циљ друштвених промена због којих се "револуција" покреће.

Језик и институције демократије данас су одомаћени на свим континентима и у свим крајевима света. Оне су у оптицају и када су на дневном реду веома различите, често противречне појаве. Било да је човек конзервативац или револуционар, сви се позивају на демократију и настоје да се прикажу као њени главни (једини прави) протагонисти.

Упоређујући појам демократије са такође изузетно фреквентним али недовољно јасним појмовима слободе и права, Џон Кин (John Keane) говори о камелеонском квалитету демократије којим она придобија за себе оне који у том термину виде много тога различитог па и супротстављеног! Као решење, Кин нуди концепт непретенциозне демократије под којим подразумева различите форме ове појаве, али са неопходном есенцијалном садржином која је њен неизоставни део (Кин, 2010: 21-31).

Оно што је диференција специфика демократије, не односи се ни на процедуре ни на садржај, већ на њен посебан однос према моћи. Наиме, она је од свих облика владавине најосетљивија на моћ и у суштини подразумева денатурализацију моћи. "Она заступа уједначавање моћи и стоји насупрот манипулацији, ауторитативности и насилној власти" (Кин, 2010: 21-31). И површна анализа односа државе и демократије данас, може да доведе до разочаравајућег закључка о стварном односу ових категорија чак и у развијеном свету. Целокупан актуелни међународни поредак, како уочава професор Мирослав Печујлић, заснива се на економској експлоатацији, политичкој доминацији и духовној манипулацији (Печујлић, Милић, 1994: 201) - елементима директно супротним од онога што је суштина (непретенциозне) демократије.

Колико је неки поредак заиста толерантан, демократски и имун на изазове моћи, најбоље може да се провери на његовом односу према окружењу и решењима која нуде други. "Да ли би Запад могао да поднесе форме демократије које су створили његови непријатељи" - пита се турски писац Орхан Памук у свом роману Снег (Кин, 2010: 26).

Не улазећи дубље у покушаје дефинисања демократије и разлике у њеном схватању кроз историју, навешћемо само чињеницу да нпр. Џон Драјзек (John Dryzeck), наводи 56 придева демократије, а Дејвид Хелд (David Held) описује 
чак 11 типова овог поретка (видети шире у: Подунавац (уредник), 2010: 15. и 16). Демократију разматрају од оне првобитне и наивне слике о народу способном да управља сам собом и заједнички - јавно решава сва општа питања, до онога што у том процесу види Гор Видал (Gore Vidal): „Демократија је место где се бројни избори одржавају по високој цени без проблема и са узајамно замењивим кандидатима“ (Кин, 2010: 30).

У контексту разматрања суштине „шарене револуције“, треба уочити да се западно тумачење демократског система или процеса демократизације (прелаз из аутократског у демократски систем) заснива на постојању једног идеално типског модела друштва оличеног у либералним демократијама западног типа, на основу кога се упорећују резултати транзиције недемократских режима. При томе, тај идеални модел који служи као мерило, није у довољној мери дефинисан, већ се заснива на постојању неколико обележја за која се сматра да релевантно одређују карактер демократског устројства. Тако, нпр. Линц (Juan Jose Linz) и Степан (Alfred Stepan) сматрају да у демократском систему постоји плурализам у области привредне аутономије и у унутрашњем животу друштвених организација; да је изражено широко залагање за остваривање статуса грађана, поштовање мањинских права и подршку индивидуализма. Кроз формирано цивилно друштво и политичке организације, провејава такмичарски дух, уз јасно дефинисану правну заштиту читавог система. Руководеће гарнитуре образују се на периодичним слободним изборима а власт врше у оквирима владавине права (видети шире у: Линц, Степан, 1998: 58-80).

На бази оваквих и сличних теоријских схватања, урађени су механизми квантификације наведених битних обележја друштва и државе на основу којих се мери ниво њихове демократичности. Најзаступљенија, у том смислу, су истраживања организације Freedom House: Freedom in the World и Nations in Transit (NIT). Према првом истраживању, државе се рангирају на основу испитивања нивоа политичких права и слобода на скали од 1 до $7 .^{2}$ Код истраживања NIT, рангирање се такође врши од 1 до 7, али се као индикатори узимају: изборни процес, цивилно друштво, независни медији, демократска управа на нивоу државе и у локалним заједницама, независно судство и корупција. ${ }^{3}$

2 Државе које имају од 1,0 до 2,5 индексних поена, рангирају се као "слободне" односно демократске; оне са 3,0 до 5,0 поена - "делимично слободне" и од 5,0 до 7,0 су "неслободне", односно ауторитарне државе.

3 Државе које имају од 1 до 3 бода, сврставају се у "консолидовану демократију", од 3 до 4 бода су "полуконсолидоване демократије", од 4 до 5 бодова имају "транзициони" или "хибридни" режими, од 5 до 6 поена су "полуконсолидовани ауторитарни" режими и од 6 до 7 поена - "консолидовани ауторитарни" режими. 
Овде се поново намеће још један крупан методолошки проблем везан за настојање да се поједине изразито квалитативне и променљиве категорије као што су: остваривање и заштита слобода и права, функционисање система владавине права, аутономија организација, улога медија, карактер политичке културе, улога цивилног друштва и сл., прикажу квантитативним показатељима.

Не улазећи дубље у анализу валидности резултата истраживања која се спроводе у оквиру организације Freedom House, као илустрацију релативности покушаја квантификације сложених друштвених појава, навешћемо само податак да је после распада СССР-а, Русија, по питању нивоа политичких права и грађанских слобода, била оцењена као "делимично слободна" (оцена 3, која се граничи са статусом "слободна"). Такав положај остаје све до краја Јељциновог мандата. Од 2 000. године, а нарочито после "шарених револуција" у Грузији и Украјини, Русија се сврстава у "неслободне" државе, са 5 и (од 2004. године) 6 индексних поена. Ако само и површно упоредимо ситуацију у Русији у та два периода, можемо видети да је у време статуса "делимично слободна" - држава практично доживела економски крах, уз дивљу приватизацију и пљачку државне имовине; земља такорећи није функционисала као целина и као врхунац: дошло је до бомбардовања парламента од стране извршне власти. У време њеног статуса "неслободна" држава (период "Путинове" Русије), дошло је до консолидације територијалне целовитости земље, враћен је целокупан спољашњи дуг, а институције су, макар и формално и са пуно недостатака, ипак функционисале према уставним решењима. У истом том периоду (2005. године), Грузија је са оценом 3 била у групи "делимично слободних" држава, а Украјина је са 2 поена категорисана као "слободна" ( Freedom House, reports, 2012)!

\section{2. Методологија извођења "шарених револуција"}

По правилу, под "шареном револуцијом" подразумева се процес смене владајућих структура под притиском масовних уличних акција протеста и уз подршку невладиних организација финансираних из иностранства ( Почепцов, 2005: 11).

Ипак, како историјска пракса показује, масовни улични протести и инострана подршка опозиционих покрета, који теже смени режима, присутни су у свакој револуцији. Сходно томе, ови елементи не могу да чине суштину "шарене револуције".

Пре свега, класичне револуције XIX и XX века, "у својој почетној фази нису ни чисто политички, ни економско-политички процеси, већ су, пре свега, идеолошки и духовно-морални преврат, који се прво дешава у друштвеној свести, у "систему вредности" основног дела друштва - а тек затим у његовом друштвеном бићу", односно у политичко-социјалним и економским институцијама после 
освајања власти од стране револуционарне партије или коалиције (Фефелова, 2010: 16).

Другим речима, суштина револуције, у њеном традиционалном схватању, састоји се у йосебној револуционарној идеји, новој идеолошкој докиирини, која формира највише вредности и врховни смисао постојања човека у "новом исииоријском йројекӣ⿲二". Практична реализација те идеје је срж револуције, односно, револуционарног процеса.

Са те тачке гледишта, "шарене револуције" немају, па чак и не претпостављају никакве нове велике идеје. Реч је или о специфичном настојању да се, у конкретним условима, имплементира позната идеја западне либералне доктрине, или о неким радикалним пројектима, који се рађају у оквиру религијских учења, пре свега у исламу. Тако посматране, "шарене револуције" не садрже, нити подразумевају реализацију неког новог идејной йроцеса. Упорно инсистирање на "демократском" карактеру "шарених револуција", у ствари је својеврсно "попуњавање" идејног вакуума с обзиром да је идеологија неизоставни пратилац сукоба елита и социјалних група које их подржавају. Без адекватног везивања за демократију, "шарена револуција" објективно не би била у стању да добије широку подршку социјума способну да генерише, мобилише и појача латентне и манифестне аспекте незадовољства маса.

То најбоље доказује "постреволуционарни" развој земаља у којима су се десиле такве промене. Борба за власт и нови баланс снага постају доминантна обележја односа, не само међу снагама везаним за стару и нову власт, већ и у оквиру самих "револуционарних" фракција. Сукоб елита брзо се преноси и на само друштво, а плодови демократије - како су одсуствовали у претходном режиму, тако изостају и после "демократизације" система. Илустрације ради, у оквиру "демократског блока" у Србији (Демократска опозиција), деловале су чак 24 политичке странке - конгломерат програмски веома различитих политичких оријентација. Колико су оне стварно одражавале вољу грађана, најбоље говори чињеница да највећи број тих политичких организација није био способан да достигне изборни праг самосталним наступом на изборима. Одсуство неке више кохезионе силе (револуционарне идеологије), веома брзо је уклонило завесу са попришта на коме се, као и раније, одвијала класична борба за власт. Слично је било и у Украјини где је брзо дошло до раскола у редовима партије "Наша Украјина" и политичке кризе у односима главних актера - Виктора Јушченка и Јулије Тимошенко. "Демократске" снаге у Грузији, "предупредиле" су сличан расцеп победничког блока, убиством Зураба Жваније (министра а затим и премијера Сакашвилијевог режима) који је својим потенцијалом утицаја претио да заустави процес ауторитарне консолидације власти. У Киргизији такође није сачувано једниство "револуционарних" снага. Политички тандем председника Бакије- 
ва и премијера Кулова није дуго остао на сцени. Бакијев није превише желео да ризикује инсистирајући на опстанку свог председника владе, да би релативно брзо и он сам постао жртвом "демократских промена" у земљи .

С друг стране, одсуствују и услови карактеристични и принципијелно важни за класичне револуције. Подсетимо се учења класика: "...револуција није могућа без револуционарне ситуације, али свака револуционарна ситуација не доводи до револуције". Као што је познато, Владимир Иљич Лењин, указивао је на три главна индикатора револуционарне ситуације (курзив је свугде наш М.M., J.П., 3.К):

„1. Немогућност владајуће класе да сачува своју власт у непромењеном облику;... Да би револуција йочела обично није довољно йо шимо „нижи не желе“, већ се захиевва и да „виши не моіуу“ “а живе йо сииаром;

2. Заоштравање сиромаштва и несреће угњетених класа, више неїо ший је тио уобичајено;

3. Значајно повећање активности маса, које у „мирно“време спокојно дозвољавају да буду пљачкане, али које у бурна времена, услед горе наведених разлога, што општом кризном ситуацијом, што самим „врхушкама“, бивају примамљене на самосталан историјски наступ.“

Ипак, као што је већ речено, не доводи свака револуционарна ситуација до револуције. Револуција настаје "само из такве ситуације, када се горе наведеним објективним променама придруже субјекӣивне, тј. способност револуционарне класе на револуционарна масовна дејства, довољно снажнна да сломе (или доломе) стару власт, која никада, чак ни у кризи, неће „пасти“ уколико је не „придаве“(Ленин, 1969: 218-219).

У суштини, ни у једној од земаља у којима су биле инспирисане "шарене револуције", није било револуционарне ситуације. Мора се истаћи да је за успех "шарене револуције" неопходан моменат највећих тешкоћа с којима се суочава власт, односно период недвосмисленог погоршања њеног економског или политичког положаја као што је пораз у рату, међународне санкције, економска криза итд. (Подробније у: Пономарева, 2011а и б). У земљама у којима су се догодиле "шарене револуције", није било ни револуционарне класе способне и организоване да изврши насилни преврат, а још мање консолидованог цивилног друштва спремног да квалитетно преузме од државе, већину заједничких послова заједнице. Промене су се дешавале услед мобилисаног незадовољства маса, неспособности и неодлучности режима да сачува власт и уз свеобухватну подршку са стране, али ипак релативно мирно и практично у оквиру постојећег административно-институционалног оквира. Због тога украјински професор Јуриј Мацијевски сматра да је "некоректно говорити о томе да се револуција може од- 
играти за време избора јер су револуције политичке промене које се одигравају уз помоћ насиља (пуча и преврата) и излазе из уставно-правног оквира". Своју тврдњу Мацијевски поткрепљује примером Украјине где су се "одлуке Уставног суда о трећем кругу председничких избора одигравале у изузетним, али ипак легалним условима" (Мацієвський, 2005: 36-37).

На тај начин, "шарене револуције" не йосӣављају исйред себе најважнији

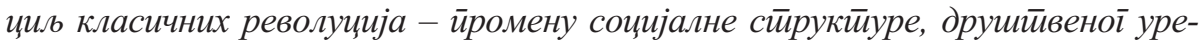
Ђена и форме сойсиввеносиии. Оне су ,намеюене“ иревасходно за смену йолийичких лидера. То потврђује и следећа особеност "шарене револуције", везана за факторе њеног неуспеха и пропасти. Кључно место, у оквиру тих фактора, заузима „постојање одлучног и чврстог шефа државе који се не устручава да „употреби власт“ како би пресекао све незаконите и провокативне акције „обојених револуционара“", чак и ако су релативно масовне (Фефелова, 2010: 18).

Другим речима, развој „обојеног“ револуционарног процеса проводи се у условима „ненасилног“ одузимања власти од оних лидера који су неодлучни у њеној употреби или су неспремни за примену легитимног и релативно обимног насиља (растеривање несанкционисаних митинга, протесних окупљања и шетње и сл.). Снага законите власти у целини, и националног лидера посебно, огледа се и у постојању верних и лојалних структура силе које је немогуће ни застрашити нити поткупити.

Значај овог фактора неки аналитичари оцењују тако високо да сматрају, да је против демонстраната у Источној Немачкој, својевремено била примењена сила као на тргу Тјенамен у Кини 1989. године, највероватније да не би ни дошло до каснијег слома комунистичких режима.

Следећа одлика "шарене револуције" јесте велика брзина и одлучност деловања. Масовном применом финансијских и информационих ресурса, време за припрему рушења режима скраћује се на 1,5 до две године. Захваљујући томе, није неопходна дуготрајна припрема дисидената, изнурујућа вишегодишња пропаганда, увлачење земље у исцрпљујућу трку у наоружању и економски крах, као што је био случај са СССР-ом и његовим савезницима из социјалистичког табора. Све ове етапе пролазе кроз убрзани режим, уз коришћење могућности постиндустријског и информатичког друштва.

Ова карактеристика доводи до следећег обележја "шарене револуције", а то је стварање и коришћење технологије "мрежног маркетинга", "безлидерских по-

\footnotetext{
${ }^{4}$ Голем - по јеврејској митологији, глинени великан створен ради заштите јеврејског народа; на основу мита, створене су бројне легенде међу којима је најраспрострањенија она која говори о вештачком човеку (Голему), створеном да обавља разне "црне" послове и тешке мисије ради помоћи јеврејским општинама.
} 
крета", "рекламног менаџмента" и гигантских "партија-Голема"4, које обухватају велики део протестног електората свих спектара, привученог различитим, често противречним, обећањима. Како пише П. Иљченков "одсуство јединственог јавног руководства обезбеђује постизање високог степена отпорности тих покрета, омогућава им окупљање просто неспојивих друштвених елемената. Та "партијаГолем", активира се у моменту „Х“, при појави неопходности да се народ изведе на улицу ради провођења масовних акција грађанске непослушности.

После остваривања циља, она може да буде потпуно ликвидирана посредством уграђеног механизма самоуништења који спречава да се те масовне али безглаве партије преврате у "хегемона" или у партије диктаторско-популистичког типа. Механизам самоуништења лежи, како у тајни њиховог рађања и финансирања, тако и у превеликом спектру учесника који могу да се смире тек са победом над "мрским диктатором", иако "светлу будућност" схватају потпуно различито“ (Ильченков, 2008: 61).

Тако су функционисали: покрет "Отпор" у Србији; "Сксела" и "Бекум" у Јерменији; "Кмара" у Грузији; "Покрет 6. април" у Египту и др. Слично настоје да се организују и делују и "Движеније-31", "Стратегија-31", "Солидарност" и "Лига избиратељеј" у савременој Русији.

Разлика између "шарене" и класичне револуције огледа се и у разликама у процесу даљег управљања садржајем и активностима укупног пројекта. Док је управљање класичном револуцијом практично трајан процес, код "шарене револуције", снаге које управљају њоме (политичка технологија) само дају почетни импулс, а "револуција" се затим развија по сопственим законима, што је додатни доказ тезе да јој је основни циљ смена режима.

\section{3. "Мека сила" као главни фактор "шарених револуција"}

Истражујући природу "шарене револуције", посебна пажња мора да се усмери на тзв. меку силу (soft power).

Аутор теорије "меке силе" је професор Јавне административне школе "Кенеди" при Харвардском универзитету - Џозеф Самјуел Haj (Joseph Nye). Треба имати на уму да Нај није само продукт академске средине већ је и човек из света практичне политике 5 .

${ }^{5}$ У администрацији Била Клинтона, Нај је био помоћник шефа Пентагона за међународну безбедност; у периоду 1993-1994. године, био је на челу Националног обавештајног савета САД. Поред тога, био је члан Извршног комитета Трочлане комисије која периодично заседа у Савету за међународне односе. Такође, професор Нај је руководио Институтом за истраживања у области безбедности "Исток-Запад" и Међународним институтом за стратегијска истраживања. По доласку Обаме на чело државе, укључен је у рад Центра за нову америчку безбедност и у Пројекат за реформу националне безбедности САД. 
Иначе, као што је већ истакнуто, пракса преласка из науке у политику; из политике у обавештајне институције; из обавештајних бироа у науку и сл. - широко је присутна на Западу. Циљ оваквих акција јесте - максимално широко пласирање и реализација интерса одређене елитне групе. Друкчије речено, теоријска достигнућа доктора Наја имају јасан практичан значај, тј. усмерена су на обезбеђење и ширење, колико-год је то могуће, доминантног утицаја Запада, пре свега САД, на све главне процесе у свету.

Професор Нај је термин мека моћ први пут употребио у својој књизи "Предодређени да воде" (Nye, 1990). Још тада, у доба пуне еуфорије због победе САД и Запада у хладном рату, он је желео да укаже на значај немилитарних облика моћи, који ће посебно место морати да заузму у периоду који је долазио. "Тврда сила" или "тврда моћ" представља могућност принућивања других на основу сопствене војне и економске моћи. "Мека сила" постоји тамо где једна држава привлачи друге својом културом, политичким идеалима и програмима. То је „моћ да се добије оно што се жели захваљујући привлачности а не принуди или плаћању. Она потиче од атрактивности културе, политичких идеала и конкретних политика одређене земље." Упоређујући методе тврде и меке моћи, Нај наглашава да прва делује путем принуде, а ова друга путем завођења. Многе вредности као што су: демократија, људска права или индивидуалне могућности јесу, по Нају, управо дубоко заводљиве и веома привлачне идеје. Међутим, ако се у њиховом сервирању осети надменост и лицемерје, могу да се преврате у своју супротност.

С обзиром да је, по мишљењу Наја, "мека сила" одиграла одлучујућу улогу у хладном рату, њену примену свакако треба наставити и у XXI веку. Тај тип утицаја, односно форма власти, непосредно је везан за информатичку револуцију и раст тог ресурса, пре свега за његову брзину ширења путем Интернета (Видети шире у: Най, 2006). Ипак, главни смисао "меке силе" лежи у чињеници да је то "привлачна власт". То је власт, заснована не само на убеђивању, наговарању или способности да се људи покрену и ураде нешто на основу понуђене одговарајуће аргументације, већ и на "вредностима" које ту власт чине привлачном. У суштини soft power је "власт информација и образаца" која се уз то довољно лако контролише. Главна обележја су јој: нематеријалност, информатичка засићеност и покретљивост.

Руски писац и публициста, Фјодор Рјазаков, добро примећује да историја не може да се "оседла" само насилним средствима! За то је неопходно и "рекодирање" свести, што значи да се мора изменити, не само свет информација већ и свет симбола. При томе, управо симболичка сфера јесте најважнија јер се на њој, у најзначајнијој мери, и опире социјално сећање друштва којим се изграђује отпорност на рушилачке тежње са стране као и на форме самоуништења. Ру- 
ски психолог Марија Холкина наглашава да: "У сваком друштву, истовремено са реформама, превратима и револуцијама, проводе се и тзв. симболичке револуције које треба суштински да измене слику света. При томе се остварује радикална ревизија "симболичког капитала", који се таложио у току претходне историјске етапе". Према Холкиној, промена симболичке хијерархије, својствена симболичким револуцијама, проводи се по приближно оваквој шеми: "1) проводи се смена сакралне зоне: друштво скида заштиту од својих претходних богова - распламсава се критика која ствара простор за нове богове; 2) нова сакралност успоставља се прецизним избором симбола - проводи се смена назива градова, улица, замена споменика; 3) као наставак претходних етапа долази до смене зоне агресије: друштво мења хијерархију у систему "друг-непријатељ"; 4) стари текстови губе своју актуелност; продукује се велика количина идеолошких текстова који треба да изврше промену политичке декорације; 5) на политичку сцену испливавају специјалисти вербалног жанра - новинари, писци, научници; 6) симболички процеси, који на први поглед изгледају неконтролисани, у суштини су прецизно усмерени ка одређеном циљу...Уметност манипулације састоји се у томе да се усмери процес уобразиље у потребном смеру али тако да човек не примети њен скривени утицај" (Раззаков, 2011: 20).

"Мека власт" управо и подразумева рад са свешћу (и подсвешћу) посредством информација, знања и културе. Конкретно, то се реализује, како пише Џозеф Нај, по следећем: "идеали и вредности које Америка „експортује“ у мозгове више од пола милиона страних студената који се сваке године обучавају на америчким универзитетима, а затим враћају у своје земље, или у свест азијских привредника који се враћају кући после проведеног стажирања или рада у Силиконској долини, усмерени су на то да се формирају елите по сопственој мери." Значи, "мека власт", само посредством образовања "обезбеђује да се код страних гостију формира одређени поглед на свет који одражсава вредносне оријенйације држсаве домаћина (курзив је наш -М.М. Ј.П., З.К) и омогућава да се може и убудуће рачунати на њихов добронамерни однос према земљи у којој су боравили. То се постиже на следећи начин: 1) боравак учесника образовних програма у земљи подразумева упознавање с политичким и економским моделом друштва, приближавање култури земље домаћина и њеним вредностима; 2) конкурсним одабиром добитника награда и стипендија, издвајају се најперспективнији представници у одређеним областима привредне и научне делатности; 3) после завршетка обуке, с дипломцима се одржавају тесне везе у оквиру друштвених мрежа, различитих истраживачких центара, што омогућава држависпонзору да утиче на иностране елите или да користи њихове интелектуалне ресурсе за сопствени интерес. Такав приступ широко примењују САД)" (Най, 2006: 176-177). 
Ресурсна база "меке силе", наравно, није ограничена само на програме обуке. Soft power користи читав спектар културних, информационих, обавештајних, мрежних, психолошких и других технологија. Све то потврђује констатацију немачког издавача Ј. Јофе, наведену у књизи Џ. Наја да је: "гипка власт Америци значајнија од њене економске или војне моћи. Америчка култура, била она на ниском или високом нивоу, свуда продире са интензивношћу која је постојала само за време Римске империје, само са новом карактеристичном особеношћу. Деловање Рима или Совјетског Савеза у области културе некако се заустављало на нивоу њихових војних граница, док америчка гипка власт управља империјом и тамо где Сунце никад не залази " (Най, 2006: 180).

\section{4. Емпирија "арапског пролећа"}

Управо на горе изложени начин припремане су протесне снаге "шарених револуција" у арапским земљама. Њихови програми финансирани су и подржавани преко различитих фондова и других невладиних структура.

Примера ради, делатност опозиционог покрета "6. април" у Египту, подржавана је организационо-информационим ресурсима мреже Global Voices коју финансира Фордов фонд, Фонд Макартура, "Отворено друштво", као и произвођачи и дистрибутери информатичке технологије. Управо преко Global Voices, peгуларно су провођене међународне конференције и радни сусрети, додељивана средства на изабране друштвене структуре као што су: "Лекари за промене", "Новинари за промене", "Радници за промене" и др. По посебним програмима подржавана су удружења правника, женске организације и структуре националних мањина.

Циљну подршку, такође су добијале поједине редакције и издања политичких сајтова као што је "Ал-Масриал-Јум" а на међународном нивоу "Ал-Џазира". Подржавани су и поједини интелектуалци, превасходно из области средстава јавног информисања - мајстори фељтонског и карикатурног жанра.

Из материјала Wiki Leaks, објављених 29. јануара 2011. године, види се да је амерички амбасадор у Египту, Маргарет Скоби, у својим депешама, још у децембру 2008. године, спомињала покрет "6. април", који треба да буде један од основних организатора акција протеста (Bolton, 2011).

По неким подацима, група "6. април" у том моменту имала је већ 70000 људи, превасходно из редова образоване омладине. Посебан акцент био је дат на рад са коптском националном мањином. Као и у Судану, хришћанска мањина у Египту, с почетка 1980-их година, била је патронирана организацијама које су специјално биле припремљене за то - Интернационалом хришћанске солидарности (CSI) и фондом Pax Christi. На тај начин, може се закључити да су CAД 
унапред разрађивале планове револуционарног сценарија у Египту и другим земљама Северне Африке и Блиског Истока.

У поређењу с балканским периодом "шарених револуција", на арапском Истоку, масовно су коришћене социјалне мреже, пре свега Face book и Twitter. Њихови блогери били су задужени за егзалтирање аудиторја и координацију наступа. На пример, пометња у Јемену и Јордану, започета је истовремено. Такође, у исти дан, 15. јануара кренули су и нереди у Бахреину и Либији, што је немогуће ускладити без употребе мрежних структура. Због тога неки, с правом ове догађаје називају "твитер-револуцијама".

САД су, после догађаја од 11. септембра, мобилисале огромне финансијске ресурсе и формирале око 350 нових различитих програма у области образовања, културе и информација, ради ширења "демократије" и стварања слоја грађана у арапским земљама, оријентисаног на вредности и политику САД (Цветкова, 2011). Сви планови били су обједињени у оквиру обимног програма под називом: "Иницијатива за подршку партнерства на Блиском истоку" којим је управљао Стејтдепартман САД (Middle East Initiative Partnership, 2012).

Стејтдепартмент је још 2002. године јасно дефинисао циљ наведеног пројекта - осииваривање демокрайских ирреображсаја у земљама региона као што су: Алжир, Бахреин, Египат, Јордан, Кувајт, Либан, Мароко, Оман, Катар, Саудијска Арабија, Тунис, Уједињени арапски емирати, Палестинске територије, Иран, Ирак и Либија.

Те преображаје, према замисли, требало је реализовати уз помоћ пројеката усмерених на: (1) йромену ӣолитиичкой уређења путем стварања партија, припрему алтернативних политичара, еманципацију жена и формирање лојалне и демократски оријентисане омладине; (2) ирромену економскоі сисииема путем стварања слоја бизнисмена и правника који имају "западно образовање" уз истовремену промену законодавства земље; (3) реборму систиема образовања посредством укључивања жена у образовни процес, преко ревизије наставних планова и кроз обезбеђивање школа и универзитета америчким уџбеницима (Сајт организације: United States Agency for International Development, 2012).

У реализацији ових пројеката било је испробано новаторство. Први пут за 60 година постојања "јавне дипломатије", САД су измениле циљну структуру програма обучавања усмерених на ширење принципа либералне демократије. Сада, уместо постојеће елите, војске и дисидентске интелигенције, власт САД почела је да обучава омладину до 25 іодина и жене. Поред тога, Стејтдепартмен је модификовао и тактику пласирања свог утицаја. Уместо подршке политичких режима и армија, Вашингтон је почео да ствара алтернативне партије и непрофитне организације и да реформише систем образовања. 
Као резултат тога, за десет година реализације "јавне дипломатије", значајно се повећао број арапских грађана који су прошли политичку обуку, како у САД тако и у својим земљама. Ако су крајем 2 000. године, хиљаде грађана били укључени у програме размене или обуке, већ 2004-2009. године, њихов број се мерио стотинама хиљада. На пример, само из Египта, САД су 1998. године позвале на обуку из области развоја демократије око 3300 полазника, 2007. године, тај број је износио 47300 људи, да би 2008. године обуку прошло 148700 грађана! (Interagency Working Group on the U. S., 2002, 2007, 2008).

Треба имати у виду да су САД успеле да "обраде" омладину из најнеобезбеђенијих слојева друштва, која је била лишена могућности да добије образовање. Те групе младих људи - тзв. Underserved youth, припремане су у школама демократије и грађанског друштва и прошле су обуку из области политичких технологија и основа грађанске непослуштости и протеста. На тај начин, оне су постале ударни одред "демократских промена" који је само чекао час "X".

Упоредо с овим, почев од 2002-2004. године, САД су формирале десетине нових радиостаница и телевизијских канала. Најпознатији међу њима су: «Сава», «Фарда», «Слободни Ирак», «Глас Америке на курдском језику», «Мрежа персијских новости» и др. Највећи је телевизијски канал «Алхура» који покрива све земље Северне Африке и Блиског Истока. С обзиром да је крајње политизован, он је успео да привуче пажњу омладине посредством емисија као што су «Час демократије», «Мишљења жена» итд.

Упоредо с овим, посебна пажња била је посвећена припреми блогер активиста. На пример, само на бази правног колеџа Колумбијског универзитета, пред организаторима будућих акција, "презентације" су проводили кључни сарадници из кабинета председника Обаме, који су обезбедили и његову победу на председничким изборима у САД. Још једна структура била је веома важна за припрему опозиционара. To je Alliance for Youth Movements који је такође финансиран од стране Стејтдепартмента САД. У разради сценарија револуција и припреми опозиционог језгра, непосредно учешће имали су: New America Foundation - суоснивач Global Voices-a и партнер Google, Центар СЈИ и јавне политике Школе државног управљања "Кенеди" из састава Харвардског универзитета, Беркмановски центар «Интернет и друштво» из Харвардске Школе права, NEXA Center, Оксфордски институт Интернета, школе права Колумбијског и Јејлског универзитета и др. (сајт организације Movements, 2012).

\section{5. Да ли је могућа "шарена револуција"у Русији?}

Чињеница је да је у оквиру обичног чланка немогуће детаљно разоткрити природу и технологију "шарених револуција". Ипак,у потпуности је могуће доказати вештачку природу оваквих појава. Револуција у класичном схватању, 
захтева постојање два неопходна услова. "Пре свега, неопходне су одговарајуће социјално-економске и политичке претпоставке. Уз сву важност социјалноекономске компоненте, она је само неопходан, али не и довољан услов за револуцију. Револуција није могућа без организације, финансијског обезбеђења и манипулације информацијским каналима. Системски услови за револуцију постоје у многим земљама и то током дужег периода времена али, због нечега, оне се не реализују увек и на сваком месту (Фурсов, 2011).

У револуционарним потресима новог времена, огромну и нарастајућу улогу има страна финансијска и организационо-информатичка подршка антисистемским снагама. Занимљиво је да се притисцима излажу само режими тих земаља за чије је ресурсе, стратегијски или геополитички положај заинтересован Запад.

Другим речима, "шарене револуције" покрећу се у регионима који потпадају под интересе водећих субјеката светске заједнице. Активирање протестних акција у Русији после парламентарних избора 4. децембра 2011. године, упркос чињеници да је било објективних разлога за незадовољство, одговара логици "шарених револуција". О заинтересованости западних земаља за промену ситуације у Русији, како званичника тако и невладиних структура, говоре многи конкретни факти. У оквиру тога, може се навести активна подршка протестних покрета од стране Амбасаде САД у Москви и амбасадора М. Макфола лично (Тимофеев, 2012), непосредно учешће у формирању и усмеравању делатности блогер-организација као и у реализацији читаве серије специјалних програма "обуке за демократију". На пример, Амерички центар регуларно проводи округле столове мрежне Школе одговорних блогера. Треба имати у виду да су организатори Школе завршили програме стажирања у органима законодавне и извршне власти САД (Legislative Fellows Program) и другим међународним институцијама. Овај пројекат проводи се у оквиру програма Стејтдепартмента САД "Фонд за подршку иновационих пројеката програма за размену " (Alumni Engagement Innovation Fund).

Школа има за циљ да обезбеди блогере почетнике свим неопходним знањима и да им помогне да њихове блогове учини извором "независних" новости и анализа, важних за цивилно друштво. Уз помоћ пројекта, ствара се мрежа "експерата", што ће омогућити ширење искустава и давање практичних савета заинтересованим блогерима почетницима по целој Руској Федерацији. У оквиру пројекта, већ је било организованих сусрета у Санкт-Петербургу, Нижњем Новгороду и Архангелску (Сајт организације Школа ответственных блоггеров, 2012). Управо уз овакву методологију, формиране су протестне групе у Египту и Тунису. 
Поред овога, у западним политичким структурама и либералним СЈИ, непрестано се повећава негативни набој везан за ситуацију у Русији, а посебно за личност поново изабраног председника, Владимира Путина. На пример, недавно је, са говорнице Парламента, "члан опозиционе, лабуристичке партије Д. Макшејн захтевао од владе Велике Британије да саопшти руском премијеру да његово присуство као госта на лондонској Олимпијади у лето 2012. године, неће бити добродошло ако Русија не предузме мере на поправљању ситуације са правима човека (Свичеревский, 2012). При томе је, бивши заменик министра иностраних послова за Европу у влади Тонија Блера, као "крунски" аргумент навео: "ако је госпођа Тачер могла да каже „не“ за учешће Британије на Московској олимпијади, тада и Камерон, ако хоће да следи пример Челичне леди, мора да каже „не“ господину Путину (Свичеревский, 2012).

Реанимација хладног рата, која је прилично очигледна, проводи се уз значајну и озбиљну модернизацију средстава и технологије његовог вођења. Једно од њих су и "обојене револуције". Спречавање њиховог дестабилизационог и рушилачког дејства делимично се може постићи коришћењем технологије аналогне њиховој, односно, кроз провођење "антишарене револуције". Основно оружје тог отпора јесте разоткривање њихове суштине, начина припреме и реализације, као и јачање уверености у исправност и неопходност сопственог пута развоја.

Многи мислиоци који су проучавали револуције дошли су до закључка да се револуција може победити само извођењем револуције. "Извести револуциjу" у овом смислу, значи овладати њеном енергијом и усмерити је на друге циљеве, односно на решење оних проблема који су утицали да се људи прикључе "револуционерима".

"Киргиски догађаји показују једну веома важну ствар: ако хиљаду људи, који себе прогласе народом, почну нешто да траже, власт не може да се одржи уколико се не појави други народ, који излази на тај исти трг и говори: ми не желимо то што ви хоћете. Само ако међу тим народима дође до неслагања па чак и сукоба, власт постаје потребна, неопходна. Али управо народ, а не лажни "покрети" које ствара политичка технологија" (Видети шире у: Шайхутдинов, 2005).

Уколико власт не схвати сву суштину и озбиљност промена, и упорно настоји да функционише на класичан начин, неће бити у стању да заустави деловање "шарене револуције". Као најважније, она мора да прихвати реалност да целокупна пуноћа власти не треба да буде сконцентрисана у држави и да јачање власти не сме да се остварује само кроз учвршћивање државе и појачавање позиција њених "институција силе". 
Уколико се не помири са том истином, власт ће, корак по корак, наставити да губи свој народ, иако мисли да је он компактан, отпоран, непоколебљив и "стабилан", чиме ће обезбедити основну претпоставку за сопствени крах. Најпесимистичкије прогнозе, у том смислу, садрже визије чак горе од ситуације коју ствара "обична шарена револуција".

"Један од могућих сценарија за Русију јесте револуција и то не планскисистематска с једним лидером, већ "по деловима", са неколико лидера који чак и не морају бити у координацији. У Русији ће се највероватније десити неколико "шарених револуција" - происламска, сибирска, прозападна, услед чега Русија, не само да ће изгубити суштинске територије већ ће се распасти на делове" (Шайхутдинов, 2005).

Ипак, са исто толико аргумената, наступају и они који сматрају да Русија не може да буде "објект демократизације" попут земаља у којима су се десиле "шарене револуције".

Главно упориште ових схватања јесте чињеница да су основне полуге руске самобитности још увек сачуване: евроазијска позиција, нуклеарни потенцијал, људски ресурси, свест о националним вредностима и државној самобитности, енергетика и тд. Управо те вредности чине окосницу свих стратегија којима се дефинише будући развој руског друштва. Чињеница је, међутим, да ће и државе које чине основу глобализације, непрестано настоајати да проверавају Русију на издржљивост, управо наносећи ударце по тим суштинским елементима њене суверености.

Да ли ће се, поштујући сопствене услове и потребе, и у Русији постепено ослобађати потиснуто цивилно друштво и изграђивати социјална држава савременог тржишног типа или ће се латентни (и манифестни) ауторитарни елементи распламсати у облику "вучије" државе соцдарвинистичког модела у којој ће спољашње снаге наћи доста савезника, не може да предвиди политичка наука. Она само може да укаже на предности, недостатке и последице једног или другог пута. Како ће се потенцијали преточити у практична решења, зависиће од односа снага различитих, унутрашњих и спољних, политичких и других субјеката који претендују на улогу креатора руске државе и друштва.

$$
* * *
$$

Напред представљена "технологија" извођења "шарених револуција" углавном није спорна. Највећи део њених процеса не одвија се тајно нити у оквиру неких затворених система. Влада САД издваја значајна средства за реализацију принципа "хуманитарних интервенција" који је легитимисан као национални 
интерес. Његов главни садржај јесте пројектовање (америчких) друштвених вредности ван државних граница (Видети шире у: Deibel, 2007: 128). Велики број угледних Западних теоретичара у својим радовима "доказује" да сам свет има потребу за глобалним управљањем и да, у том смислу, "голијат" добија широку, јавну или прећутну, подршку (Манделбаум, 2006).

С друге стране, исти ти поступци, на Истоку се тумаче као настојање, у крајњем, да се освоје одређени природни ресурси и да се обезбеди експлоатација богатства широм света. Без настојања да дамо неки чврст закључак и коначан одговор поводом ових неслагања, издвојићемо само неколико значајних проблема и дилема које проистичу из суштине "шарених револуција" .

1) Да ли је човек заиста достигао цивилизацијски ниво у коме је срећа и благостање других главна сврха сопственог деловања?

2) Може ли у неслободном друштву човек да буде истински слободан, односно, да ли се човеку може подарити срећа?

3) У каквом односу треба да буду средства и циљеви који се желе њима постићи?

Настојања да свет постане заједница мира и прогреса увек су имала бар два супротна лика. Први представља тежњу за истинским уједињењем човечанства, стварањем "светског друштва" у коме су сви људи "грађани света" и у коме се снагом рација превазилазе крвави регионални конфликти и ствара ред на планети као услов мирног и прогресивног развоја свих држава и народа. Визија ове концепције је "Светска демократска (правна) држава" у којој ће се поштовати универзални принципи и развијати општи демократски процеси.

Други лик је тамна страна овог процеса и израз је крајње егоистичких тежњи управљача светом. Он је облик нескривене тежње за очувањем и проширивањем привилегованог положаја, пооштравањем контроле над физичким изворима богатства и настојањем да се управља људским понашањем. Његов резултат је стварање "светске ауторитарне државе". Делимично решење ове дилеме може се пронаћи сагледавањем сагласности циља и средстава.

Не може терор бити средство за успостављање слободе, лаж за долажење до истине, а диктатура за освајање демократије! Још је Волтер, у 18. веку, уочио овај проблем, истичући главни парадокс руске интервенције у Пољској: "Пример који даје царица Русије јединствен је у свету."- писао је француски просветитељ. "Она је послала четрдесет хиљада Руса да проповедају толеранцију, са бајонетима на пушкама...Она је повела армије да донесу мир...да натерају људе да подносе једни друге" (Волтер, 1966: 196). 


\section{ЛИТЕРАТУРА:}

Bunce, V., Wolchik, S. (2005). Bringing Down Dictators: American Democracy Promotion and Electoral Revolutions in Postcommunist Eurasia, First draft of a chapter prepared for Mitchell Orenstein, Stephen Bloom (eds.), Transnational and National Politics in Postcommunist Europe. < http://ru.scribd.com/doc/113605417/Bunce-American-Democracy-Promotion > 25.05.2012.

Bolton, K.R. (2011). What's Behind the Tumult in Egypt? Foreign Policy Journal, February 1. 2011. < http://www.foreignpolicyjournal.com/2011/02/01/whats-behind-the-tumult-in-egypt/ $>25.05 .2012$.

Цветкова, Н. (2011). Американский фактор в арабских революциях. Санкийиетиербурики

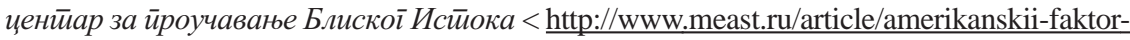
v-arabskikh-revolyutsiyakh-mobilizatsiya-protesta-cherez-publichnuyu-dip > 25.05.2012.

Deibel, T. (2007). ForeignAffairs Strategy: Logic of American Statecraft. New York: Cambridge Unuversity Press.

Фефелова, О.А. (2010). Революционные трансформации на постсоветском пространстве в контексте развития политического процесса. Авйореф. канд. йолий.наук, Москва: Акад. труда и соц. Отношений < http://www.dissercat.com/content/revolyutsionnye-transformatsii-na-postsovetskom-prostranstve-v-kontekste-razvitiya-politiche $>25.05 .2012$.

Freedom House, reports < http://www.freedomhouse.org/reports $>25.05 .2012$.

Фурсов, А.И. (2011). Последняя Большая охота капиталистической эпохи. Свободная ирресса $<$ http://svpressa.ru/society/article/51505/ > 25.05.2012.

Ильченков, П. (2008) «Эксирресс-револючия» в Сербии, Оранжевые сейи: ой Белі̄рада до Бишкека. Санкт Петерсбург: Алетейя.

Interagency Working Group on the U. S. Government-Sponsored International Exchanges and Training (IAWG). Annual Reports 2002, 2007, 2008. < http: //www.iawg.gov > 25.05.2012.

Kalin, B. (1988). Povijest filozofije. Zagreb: Školska knjiga.

Kin, DŽ. (2010). Osobenost demokratije: šta je u demokratiji dobro? U: M. Podunavac (ur.), Država i demokratija, Beograd: Službeni glasnik i Fakultet političkih nauka, str. 21-32.

Ленин, В.И. (1969). Крах II Иниеернационала, ППС. Т. 26. Москва: Политиздат.

Льюис Дж. (2012). Политика двойного участия США в России. Фонд сиирайейической культйуры $<$ http://www.fondsk.ru $>25.05 .2012$.

Linc, H., Stepan, A. (1998). Demokratska tranzicija i konsolidacija: Južna Evropa, Južna Amerika i postkomunistička Evropa. Beograd: Filip Višnjić.

Мацієвський, Ю. (2005). Помаранчева революція крізь призму транзитології. Часойис “ ̈I", Но. 40, Львів.

Mandelbaum, M. (2006). Treba li svetu Golijat - Kako Amerika deluje kao svetska vlada u 21. veku. Beograd: Filip Višnjić.

Middle East Initiative Partnership. MEPI Medregion Office < http: //www.medregion.mepi.state. gov/about-mepi.html $>25.05 .2012$.

Movements < http://www.movements.org > 25.05.2012.

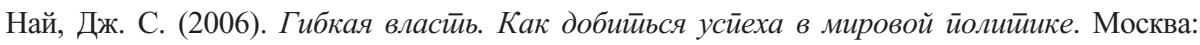
ФСПИ Тренды. 
Nye, J. (1990). Bound to Lead: The Changing Nature of American Power. New York: Basic books. Pečujlić, M., Milić, V. (1994). Sociologija. Beograd: Institut za političke studije.

Podunavac, M. (ur.) (2010). Država i demokratija. Beograd: Službeni glasnik i Fakultet političkih nauka.

Почепцов, Г. (2005). Революиия.сот: Основы ӥройесииной инженерии. Москва: Европа.

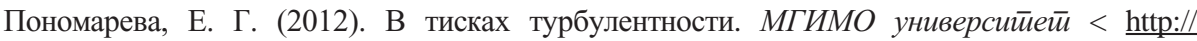
www.mgimo.ru $>25.05 .2012$.

Пономарева, Е. Г. (2011). Вирус революции и законы Токвиля. Фонд сиирайейиеской $\kappa у л ь \overline{и ̆ у р ы ~<~} \underline{\text { http://www.fondsk.ru/pview/2011/02/28/virus-revoljucii-i-zakony-tokvilja.html }}$ $>$ 25.05.2012;

Пономарева, Е. Г. (2011). Стратегия уничтожения Ливии. Фонд сиирайейической кульйуры < http://www.fondsk.ru/pview/2011/03/20/strategija-unichtozhenija-livii.html > 25.05.2012.

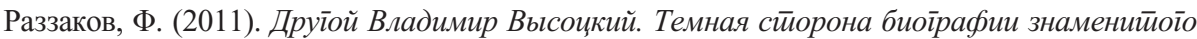

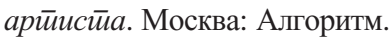

Свичеревский, М. (2012). Путина могут не пустить на олимпиаду в Лондон. Новый Рейион 2 $<$ http://nr2.com.ua/moskow/366892.html $>25.05 .2012$.

Шайхутдинов, Р. (2005). Киргизия-2005: «Демотехника» на марше. Полий. Рy < http://www.polit.ru/article/2005/04/06/demot/ > 25.05.2012.

Школа ойвейсиивенных блойеров < http://blogoschool.com/ > 25.05.2012.

Тимофеев, М. (2012). Первое публичное выступление Макфола на Гайдаровском форуме. Бизнес Online < http://www.business-gazeta.ru/video/263/ > 25.05.2012.

US AID < http://usaid.gov $>25.05 .2012$.

Volter (1996). prema: D. Olivije, Katarina Velika, N. Sad, Zagreb: Progres i Epoha. 
Miroslav Mladenović

Summary

University of Belgrade

Faculty of Security Studies

Jelena Ponomareva

Moskow State Institute of international Relations

(University) of the MFA of Russia

\section{Zoran Kilibarda}

University of Belgrade

Faculty of Security Studies

\section{THEORY AND PRACTICE OF „COLORFUL“ REVOLUTIONS}

The world, in terms of globalization did not become more stable and predictable. Its main characteristics today are: turbulence, insecurity, and growth potential for conflicts. The most important expression of compression of clamps of turbulence becomes events from 2011. Years, in many countries of North Africa and the Middle East, called the "Arab revolutions". For some, these events are coincidental and spontaneous protest "dreamers of democracy", while for others it is a result of the planned implementation of projects for a global reorganization of the world. Besides the difference in the value perception of "colored revolutions", among theorists there is no agreement even on issues of their target orientation and of their relationship to democracy, social reasonableness, and especially of compatibility of goals and the methods for their realizations.

Keywords: “colorful revolution“, globalisation, democracy, „soft power“, „Arab spring“ 